\title{
Standardization of the Recipes for Preparation of Ber Squash
}

\author{
S. Kavitha* and P. Veeranna Goud \\ Siddardh Nagar, kazipet, Warangal dist, Tealangana st, India \\ *Corresponding author
}

\section{A B S T R A C T}

\begin{tabular}{|l|}
\hline Key w or d s \\
Post-harvest, \\
Temperature, \\
Recipes \\
\hline Article Info \\
\hline Accepted: \\
30 March 2018 \\
Available Online: \\
10 April 2018 \\
\hline
\end{tabular}

The study was divided into three experiments and conducted in the PostHarvest Technology Laboratory, College of Horticulture, Rajendranagar, Hyderabad from December 2008 to February 2009. Investigations were carried out to standardize the recipes for preparation of squash, RTS (Ready to serve) and nectar from ber fruits by using different ratios of pulp and TSS levels at both ambient and low temperature conditions. The products were analyzed at every 30 days interval for their physicochemical, organoleptic characteristics.

\section{Introduction}

Sugar syrup was prepared by adding cane sugar to the boiling water. The strength of sugar syrup was determined with the help of hand refractometer.

The prepared syrup of desired concentration was filtered through a muslin cloth to remove impurities. The hot syrup and fruit pulp were mixed on weight basis as outlined in the treatments. The mixture was boiled by adding citric acid to get a consistent product. Potassium metabisulphate was added to prevent microbial spoilage. The prepared squash was filled into the pre-sterilized bottles of $200 \mathrm{ml}$ capacity and sealed with the help of crown corking machine. Then, the product was processed in hot water for 25 minutes, cooled immediately and stored at room temperature and low temperature for further observations.

Ber fruits are highly nutritious, rich in ascorbic acid and contain fairly good amount of vitamin $\mathrm{A}$ and $\mathrm{B}$, minerals like calcium, phosphorus and iron. Ber fruits are also higher in calorific value and ascorbic acid content than the orange. The fruits are easily digestible and act as laxative. The pulp is sweet and rich in flavour (Shobha and PushpaBharati, 2006)

Ber fruit is a richer than apple in protein, phosphorus, calcium, carotene and vitamin $\mathrm{C}$. it also excels oranges in phosphorus, iron, vitamin $C$, in calorific value and in carbohydrates. Full ripe fruits have food value of 20.9 calories (Jawanda and Bal, 1978). 


\section{Materials and Methods}

\section{Physico chemical parameters of the product}

The prepared squash, RTS and nectar stored both at room temperature and low temperature $\left(10 \pm 1^{\circ} \mathrm{C}\right)$ were analyzed for their chemical composition at an interval of 30 days for three months.

\section{TSS $\left({ }^{\circ} \mathbf{B}\right)$}

The percentage of total soluble solids was determined by using ERMA hand refractometer by placing a drop of the filtered juice on the prism of the refractometer and observing the coincidence of shadow of the sample with the reading on the scale and expressed as ${ }^{\circ}$ Brix.

\section{Acidity (\%)}

$10 \mathrm{ml}$ of homogenized sample was taken and made up to $100 \mathrm{ml}$ volume in a volumetric flask. The contents were filtered through Whatman No.1 Filter paper. An aliquot of 10 $\mathrm{ml}$ was taken for titration against $0.1 \mathrm{~N} \mathrm{NaOH}$ using phenolphthalein as an indicator. The turn of aliquot to light pink colour which persists for 15 seconds was considered as an end point. The titratable acidity was estimated in terms of percent citric acid (Ranganna, 1986).

Factor for acidity $=1 \mathrm{ml}$ of $\mathrm{N} / 10$ $\mathrm{NaOH}=0.0064 \mathrm{~g}$ of citric acid.

Acidity $=$ Titre value $\mathrm{x}$ Normality of $\mathrm{NaOH} \mathrm{x}$ $0.0064 \mathrm{X} 100 /$ Volume of aliquot taken

\section{Ascorbic acid (mg/100ml)}

$10 \mathrm{ml}$ of juice was blended with three percent metaphosphoric acid (HPO3) and volume was made up to $100 \mathrm{ml}$ with three percent HPO3.The content after shaking well were filtered through Whatman No.1 filter paper. Ten $\mathrm{ml}$ of filtrate was titrated against 2,6dichlorophenol-indophenol dye until pink colour persisted for at least 15 seconds (AOAC, 1965).

\section{Reducing sugars (\%)}

Reducing sugars were determined by the method of Lane and Eyon (AOAC, 1965). Twenty five $\mathrm{ml}$ of a fruit juice was taken and transferred to $250 \mathrm{ml}$ volumetric flask. Two $\mathrm{ml}$ of lead acetate solution (45\%) was added to flask for precipitation of colloidal matter. Potassium oxalate (22\%) of $2 \mathrm{ml}$ was added in this solution to precipitate the lead and the volume made up to $250 \mathrm{ml}$ using distilled water. The contents were then filtered through Whatman No. 1 filter paper after testing a little of filtrate for its freedom from lead by adding a drop of potassium oxalate. Reducing sugars in the lead free solution was taken in burette and titrated against $10 \mathrm{ml}$ of standard Fehling's solution mixture of A and B (1: 1) using methylene blue as an indicator till the end point was indicated by the formation of brick red precipitate. The titration was carried out by keeping the Fehling's solution boiling on the heating mantle. The results were expressed as per cent reducing sugar. $10 \mathrm{ml}$ of Fehling solution $=0.05$ glucose .

\section{Total sugars (\%)}

Total sugars were determined following the method described by Lane and Eyon (AOAC, 1965). A quantity of $50 \mathrm{ml}$ lead free filtrate was taken in a $100 \mathrm{ml}$ volumetric flask and to it $5 \mathrm{ml}$ of concentrated $\mathrm{HCl}$ was added, mixed well and then kept for 24 hours at room temperature. Acid was then neutralized with $\mathrm{NaOH}$ using a drop of phenolphthalein as an indicator till the pink colour persisted for at least few seconds. Then volume was made up to $100 \mathrm{ml}$. Total sugars were then estimated by taking this solution in a burette and titrating it 
against standard Fehling's solution mixture of $\mathrm{A}$ and $\mathrm{B}$ (1:1) using methylene blue as an indicator and taking brick red colour as an end point.

\section{Results and Discussion}

\section{Experiment 1: Standardization and storage studies of ber squash}

Ber squash was prepared and stored both at room and low temperatures. They were analyzed for total soluble solids, titratable acidity, ascorbic acid, total sugars, reducing sugars, non-reducing sugars and overall acceptability at 30 days interval.

\section{Total Soluble Solids $\left({ }^{\circ}\right.$ Brix $)$}

The data pertaining to TSS of ber squash during storage is presented in the table (1). There was a significant increase in total soluble solids of ber squash during storage period. It rises from $42.68^{\circ} \mathrm{B}$ to $43.91^{\circ} \mathrm{B}$ on 90 days of storage. Among the treatments T4 recorded significantly higher TSS (46.03) in Squash over rest of the treatments. It followed by T8 (45.41) and was on par with T6 (45.36). Significantly lower TSS was recorded with T5 (40.49). The interactions between days of storage and treatments were found to be significant. On initial days of storage of ber squash, TSS content in T1 (40.30), T3 (40.07), T5 (40.02) and T7 (40.27) did not differ among themselves. However T8 recorded significantly higher TSS (45.30).

On 30th day, T2 (45.55) and T8 (45.32) were on par in recording TSS content in squash. Similarly on both 60th and 90th day of storage, there was no significant Difference between T6 and T8 with regard to TSS content of squash. Significantly higher TSS (46.78) was recorded with T4 on 90th day of storage of squash (Bal and Chauhan, 1981).

Table.1 Changes in TSS $\left({ }^{\circ} \mathrm{B}\right)$ of squash during storage at ambient and low temperature

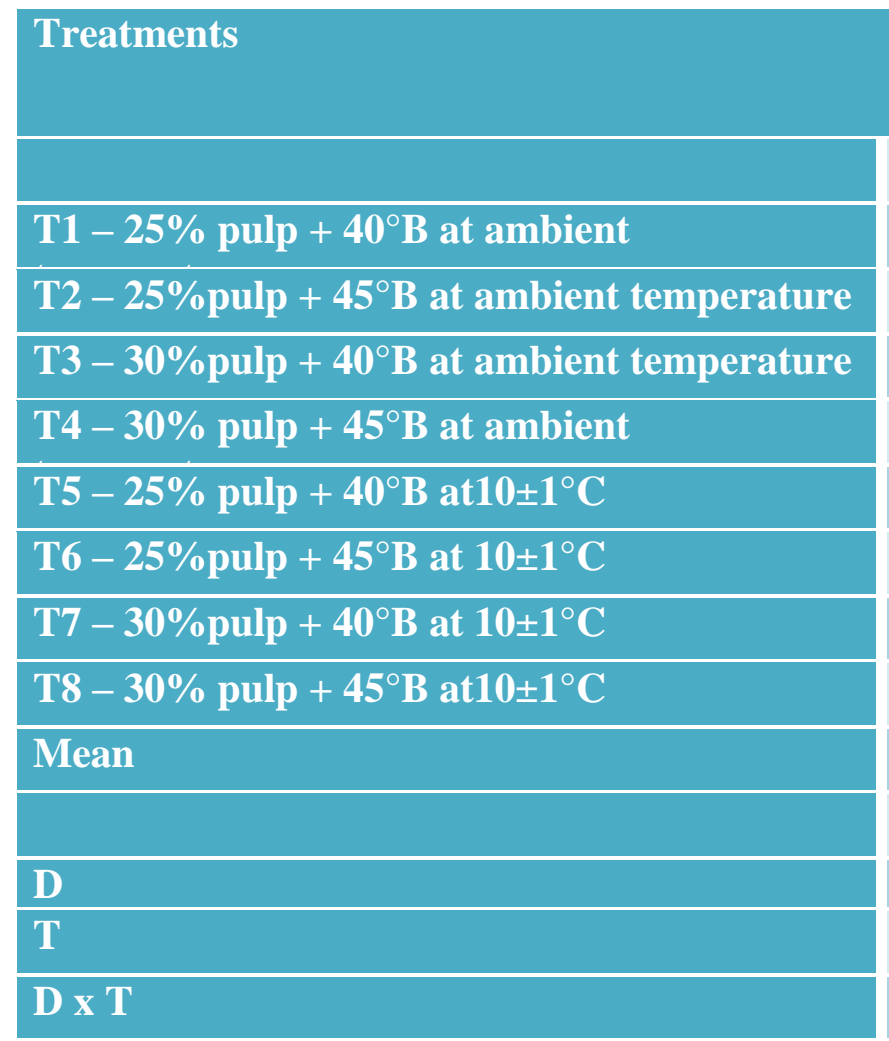

\begin{tabular}{|c|c|c|c|c|}
\hline & \multicolumn{3}{|c|}{$\mathbf{T S S}\left({ }^{\circ} \mathbf{B}\right)$} \\
\hline & & \multicolumn{3}{|c|}{ Days of storage } \\
\hline $\mathbf{0}$ & 30 & 60 & 90 & Mean \\
\hline 40.30 & 40.45 & 41.81 & 42.30 & 41.21 \\
\hline 45.21 & 45.55 & 45.94 & 46.38 & 45.77 \\
\hline 40.07 & 40.90 & 41.89 & 42.79 & 41.42 \\
\hline 45.12 & 45.91 & 46.29 & 46.78 & 46.03 \\
\hline 40.02 & 40.40 & 40.66 & 40.89 & 40.49 \\
\hline 45.18 & 45.28 & 45.39 & 45.59 & 45.36 \\
\hline 40.27 & 40.66 & 40.85 & 40.95 & 40.68 \\
\hline 45.30 & 45.32 & 45.47 & 45.57 & 45.41 \\
\hline \multirow[t]{5}{*}{42.68} & 43.06 & 43.54 & 43.91 & \\
\hline & & SEd & CD $(5 \%)$ & \\
\hline & & 0.08 & 0.16 & \\
\hline & & 0.06 & 0.11 & \\
\hline & & 0.16 & $0.32 *$ & \\
\hline
\end{tabular}


Table.2 Changes in acidity (\%) of squash during storage at ambient and low temperature

\begin{tabular}{|c|c|c|c|c|c|}
\hline \multirow{2}{*}{\multicolumn{3}{|c|}{ Treatments }} & \multicolumn{3}{|c|}{ Acidity (\%) } \\
\hline & & & \multicolumn{3}{|c|}{ Days of storage } \\
\hline & $\mathbf{0}$ & 30 & 60 & 90 & Mean \\
\hline $\mathrm{T} 1-25 \%$ pulp $+40^{\circ} \mathrm{B}$ at ambient temperature & 1.03 & 0.88 & 0.82 & 0.75 & 0.87 \\
\hline $\mathrm{T} 2-25 \%$ pulp $+45^{\circ} \mathrm{B}$ at ambient temperature & 1.04 & 0.91 & 0.86 & 0.78 & 0.90 \\
\hline $\mathrm{T} 3-30 \%$ pulp $+40^{\circ} \mathrm{B}$ at ambient temperature & 1.01 & 0.94 & 0.85 & 0.78 & 0.89 \\
\hline T4 $-30 \%$ pulp $+45^{\circ} \mathrm{B}$ at ambient temperature & 1.00 & 0.93 & 0.86 & 0.82 & 0.90 \\
\hline $\mathrm{T} 5-25 \%$ pulp $+40^{\circ} \mathrm{B}$ at $10 \pm 1^{\circ} \mathrm{C}$ & 1.01 & 0.97 & 0.91 & 0.88 & 0.95 \\
\hline T6 $-25 \%$ pulp $+45^{\circ} \mathrm{B}$ at $10 \pm 1^{\circ} \mathrm{C}$ & 1.00 & 0.97 & 0.91 & 0.89 & 0.94 \\
\hline $\mathrm{T} 7-30 \%$ pulp $+40^{\circ} \mathrm{B}$ at $10 \pm 1^{\circ} \mathrm{C}$ & 1.00 & 0.97 & 0.94 & 0.91 & 0.96 \\
\hline $\mathrm{T} 8-30 \%$ pulp $+45^{\circ} \mathrm{B}$ at $10 \pm 1^{\circ} \mathrm{C}$ & 1.00 & 0.97 & 0.95 & 0.95 & 0.97 \\
\hline \multirow[t]{2}{*}{ Mean } & 1.01 & 0.94 & 0.89 & 0.85 & \\
\hline & & & SE & CD & \\
\hline $\mathbf{D}$ & & & 0.01 & 0.02 & \\
\hline $\mathbf{T}$ & & & 0.01 & 0.02 & \\
\hline $\mathbf{D} \times \mathbf{T}$ & & & 0.02 & $0.04 *$ & \\
\hline
\end{tabular}

Table.3 Changes in ascorbic acid (mg/100g) of squash during storage at ambient and low temperature

\begin{tabular}{|l|}
\hline Treatments \\
\hline $\mathrm{T} 1-25 \%$ pulp $+40^{\circ} \mathrm{B}$ at ambient \\
\hline $\mathrm{T} 2-25 \%$ pulp $+45^{\circ} \mathrm{B}$ at ambient temperature \\
\hline $\mathrm{T} 3-30 \%$ pulp $+40^{\circ} \mathrm{B}$ at ambient temperature \\
\hline $\mathrm{T} 4-30 \%$ pulp $+45^{\circ} \mathrm{B}$ at ambient \\
\hline $\mathrm{T} 5-25 \%$ pulp $+40^{\circ} \mathrm{B}$ at $10 \pm 1^{\circ} \mathrm{C}$ \\
\hline $\mathrm{T} 6-25 \%$ pulp $+45^{\circ} \mathrm{B}$ at $10 \pm 1^{\circ} \mathrm{C}$ \\
\hline $\mathrm{T} 7-30 \%$ pulp $+40^{\circ} \mathrm{B}$ at $10 \pm 1^{\circ} \mathrm{C}$ \\
\hline $\mathrm{T} 8-30 \%$ pulp $+45^{\circ} \mathrm{B}$ at $10 \pm 1^{\circ} \mathrm{C}$ \\
\hline Mean \\
\hline D \\
\hline T \\
\hline D x T
\end{tabular}

Ascorbic acid (mg/100g)

Days of storage

\begin{tabular}{|l|l|l|l|l|}
\hline 0 & 30 & $\mathbf{6 0}$ & $\mathbf{9 0}$ & Mean \\
\hline 3.48 & 3.28 & 3.19 & 3.16 & 3.28 \\
\hline 3.56 & 3.37 & 3.29 & 3.20 & 3.36 \\
\hline 3.48 & 3.32 & 3.31 & 3.18 & 3.32 \\
\hline 3.80 & 3.70 & 3.59 & 3.49 & 3.65 \\
\hline 3.45 & 3.40 & 3.35 & 3.29 & 3.37 \\
\hline 3.59 & 3.33 & 3.49 & 3.42 & 3.46 \\
\hline 3.47 & 3.40 & 3.37 & 3.28 & 3.38 \\
\hline 3.75 & 3.72 & 3.69 & 3.64 & 3.70 \\
\hline 3.57 & 3.44 & 3.41 & 3.33 & \\
\hline & & SE & CD & \\
\hline & & 0.025 & 0.05 & \\
\hline & & 0.02 & 0.04 & \\
\hline & & 0.05 & $0.10 *$ & \\
\hline & & & & \\
\hline
\end{tabular}


Table.4 Changes in total sugars (\%) of ber squash during storage at ambient and low temperature

\begin{tabular}{|l|}
\hline Treatments \\
\hline $\mathrm{T} 1-25 \%$ pulp $+40^{\circ} \mathrm{B}$ at ambient \\
\hline $\mathrm{T} 2-25 \%$ pulp $+45^{\circ} \mathrm{B}$ at ambient temperature \\
\hline $\mathrm{T} 3-30 \%$ pulp $+40^{\circ} \mathrm{B}$ at ambient temperature \\
\hline $\mathrm{T} 4-30 \%$ pulp $+45^{\circ} \mathrm{B}$ at ambient temperature \\
\hline $\mathrm{T} 5-25 \%$ pulp $+40^{\circ} \mathrm{B}$ at $10 \pm 1^{\circ} \mathrm{C}$ \\
\hline $\mathrm{T} 6-25 \%$ pulp $+45^{\circ} \mathrm{B}$ at $10 \pm 1^{\circ} \mathrm{C}$ \\
\hline $\mathrm{T} 7-30 \%$ pulp $+40^{\circ} \mathrm{B}$ at $10 \pm 1^{\circ} \mathrm{C}$ \\
\hline $\mathrm{T} 8-30 \%$ pulp $+45^{\circ} \mathrm{B}$ at $10 \pm 1^{\circ} \mathrm{C}$ \\
\hline $\mathrm{Mean}$ \\
\hline $\mathrm{D}$ \\
\hline $\mathrm{T}$ \\
\hline $\mathrm{D} x \mathrm{~T}$
\end{tabular}

\section{Total sugars (\%)}

\section{Days of storage}

\begin{tabular}{|l|l|l|l|l|}
\hline $\mathbf{0}$ & $\mathbf{3 0}$ & $\mathbf{6 0}$ & $\mathbf{9 0}$ & Mean \\
\hline 37.0 & 37.07 & 37.16 & 37.18 & 37.12 \\
\hline 42.2 & 42.28 & 42.36 & 42.01 & 42.33 \\
\hline 38.0 & 38.13 & 38.16 & 38.26 & 38.15 \\
\hline 43.2 & 43.34 & 43.41 & 43.49 & 43.38 \\
\hline 37.1 & 37.15 & 37.18 & 37.22 & 37.16 \\
\hline 42.2 & 42.26 & 42.33 & 42.39 & 42.31 \\
\hline 38.0 & 38.07 & 38.14 & 38.20 & 38.12 \\
\hline 43.2 & 4329 & 43.32 & 43.36 & 43.31 \\
\hline 40.1 & 40.20 & 40.26 & 40.31 & \\
\hline & & SE & CD & \\
\hline & & 0.02 & 0.04 & \\
\hline & & 0.15 & 0.31 & \\
\hline & & 0.04 & NS & \\
\hline & & & & \\
\hline
\end{tabular}

Table.5 Changes in reducing sugars (\%) of squash during storage at ambient and low temperature

\begin{tabular}{|l|}
\hline Treatments \\
\hline T1 $-25 \%$ pulp $+40^{\circ} \mathrm{B}$ at ambient temperature \\
\hline T2 $-25 \%$ pulp $+45^{\circ} \mathrm{B}$ at ambient temperature \\
\hline $\mathrm{T} 3-30 \%$ pulp $+40^{\circ} \mathrm{B}$ at ambient temperature \\
\hline $\mathrm{T} 4-30 \%$ pulp $+45^{\circ} \mathrm{B}$ at ambient temperature \\
\hline $\mathrm{T} 5-25 \%$ pulp $+40^{\circ} \mathrm{B}$ at $10 \pm 1^{\circ} \mathrm{C}$ \\
\hline $\mathrm{T} 6-25 \%$ pulp $+45^{\circ} \mathrm{B}$ at $10 \pm 1^{\circ} \mathrm{C}$ \\
\hline $\mathrm{T} 7-30 \%$ pulp $+40^{\circ} \mathrm{B}$ at $10 \pm 1^{\circ} \mathrm{C}$ \\
\hline $\mathrm{T} 8-30 \%$ pulp $+45^{\circ} \mathrm{B}$ at $10 \pm 1^{\circ} \mathrm{C}$ \\
\hline $\mathrm{Mean}$ \\
\hline $\mathrm{D}$ \\
\hline $\mathrm{T}$ \\
\hline $\mathrm{D} \times \mathrm{T}$
\end{tabular}

Reducing sugars (\%)

\section{Days of storage}

\begin{tabular}{|l|l|l|l|l|}
\hline 0 & $\mathbf{3 0}$ & $\mathbf{6 0}$ & $\mathbf{9 0}$ & Mean \\
\hline 5.68 & 18.14 & 23.72 & 29.69 & 19.31 \\
\hline 5.9 & 18.85 & 26.12 & 31.28 & 20.54 \\
\hline 5.75 & 18.44 & 24.94 & 30.44 & 19.89 \\
\hline 5.86 & 18.77 & 26.01 & 31.07 & 20.43 \\
\hline 5.62 & 10.76 & 17.49 & 22.16 & 14.01 \\
\hline 5.94 & 12.66 & 18.84 & 22.73 & 15.04 \\
\hline 5.71 & 11.99 & 17.81 & 23.43 & 14.74 \\
\hline 5.82 & 12.34 & 18.26 & 22.04 & 14.61 \\
\hline 5.78 & 15.24 & 21.65 & 26.61 & \\
\hline & & SE & $\mathbf{C D}$ & \\
\hline & & 0.15 & 0.31 & \\
\hline & & 0.11 & 0.22 & \\
\hline & & 0.31 & $0.61 *$ & \\
\hline
\end{tabular}


Table.6 Changes in non-reducing sugars (\%) of ber squash during storage at ambient and low temperature

\begin{tabular}{|l|}
\hline Treatments \\
\hline $\mathrm{T} 1-25 \%$ pulp $+40^{\circ} \mathrm{B}$ at ambient temperature \\
\hline $\mathrm{T} 2-25 \%$ pulp $+45^{\circ} \mathrm{B}$ at ambient temperature \\
\hline $\mathrm{T} 3-30 \%$ pulp $+40^{\circ} \mathrm{B}$ at ambient temperature \\
\hline $\mathrm{T} 4-30 \%$ pulp $+45^{\circ} \mathrm{B}$ at ambient temperature \\
\hline $\mathrm{T} 5-25 \%$ pulp $+40^{\circ} \mathrm{B}$ at $10 \pm 1^{\circ} \mathrm{C}$ \\
\hline $\mathrm{T} 6-25 \%$ pulp $+45^{\circ} \mathrm{B}$ at $10 \pm 1^{\circ} \mathrm{C}$ \\
\hline $\mathrm{T} 7-30 \%$ pulp $+40^{\circ} \mathrm{B}$ at $10 \pm 1^{\circ} \mathrm{C}$ \\
\hline $\mathrm{T} 8-30 \%$ pulp $+45^{\circ} \mathrm{B}$ at $10 \pm 1^{\circ} \mathrm{C}$ \\
\hline $\mathrm{Mean}$ \\
\hline $\mathrm{D}$ \\
\hline $\mathrm{T}$ \\
\hline $\mathrm{D} x \mathrm{~T}$
\end{tabular}

Non-Reducing sugars

Days of storage

\begin{tabular}{|l|l|l|l|l|}
\hline $\mathbf{0}$ & $\mathbf{3 0}$ & $\mathbf{6 0}$ & $\mathbf{9 0}$ & Mean \\
\hline 31.3 & 18.93 & 13.44 & 7.49 & 17.81 \\
\hline 36.3 & 23.43 & 16.24 & 11.13 & 21.79 \\
\hline 32.3 & 19.69 & 13.22 & 7.82 & 18.26 \\
\hline 37.4 & 24.56 & 17.40 & 12.42 & 22.95 \\
\hline 31.4 & 26.39 & 19.69 & 15.06 & 23.15 \\
\hline 36.3 & 29.60 & 23.49 & 19.66 & 27.27 \\
\hline 32.3 & 26.08 & 20.33 & 14.77 & 23.38 \\
\hline 37.4 & 30.95 & 25.06 & 21.32 & 28.69 \\
\hline 34.3 & 24.96 & 18.61 & 13.71 & \\
\hline & & SE & CD & \\
\hline & & 0.15 & 0.31 & \\
\hline & & 0.11 & 0.22 & \\
\hline & & 0.31 & $0.62 *$ & \\
\hline
\end{tabular}

Table.7 Effect of storage period on overall acceptability in ber squash at ambient and low temperature

\begin{tabular}{|l|}
\hline Treatments \\
\hline \\
\hline $\mathrm{T} 1-25 \%$ pulp $+40^{\circ} \mathrm{B}$ at ambient temperature \\
\hline $\mathrm{T} 2-25 \%$ pulp $+45^{\circ} \mathrm{B}$ at ambient temperature \\
\hline $\mathrm{T} 3-30 \%$ pulp $+40^{\circ} \mathrm{B}$ at ambient temperature \\
\hline $\mathrm{T} 4-30 \%$ pulp $+45^{\circ} \mathrm{B}$ at ambient temperature \\
\hline $\mathrm{T} 5-25 \%$ pulp $+40^{\circ} \mathrm{B}$ at $10 \pm 1^{\circ} \mathrm{C}$ \\
\hline $\mathrm{T} 6-25 \%$ pulp $+45^{\circ} \mathrm{B}$ at $10 \pm 1^{\circ} \mathrm{C}$ \\
\hline $\mathrm{T} 7-30 \%$ pulp $+40^{\circ} \mathrm{B}$ at $10 \pm 1^{\circ} \mathrm{C}$ \\
\hline $\mathrm{T} 8-30 \%$ pulp $+45^{\circ} \mathrm{B}$ at $10 \pm 1^{\circ} \mathrm{C}$ \\
\hline $\mathrm{Mean}$ \\
\hline $\mathrm{D}$ \\
\hline $\mathrm{T}$ \\
\hline $\mathrm{D} x \mathrm{~T}$
\end{tabular}

Overall acceptability

\section{Days of storage}

\begin{tabular}{|l|l|l|l|l|}
\hline $\mathbf{0}$ & $\mathbf{3 0}$ & $\mathbf{6 0}$ & $\mathbf{9 0}$ & Mean \\
\hline 4.5 & 3.87 & 3.5 & 2.97 & 3.71 \\
\hline 4.57 & 3.67 & 3.60 & 3.20 & 3.83 \\
\hline 4.50 & 3.77 & 3.40 & 3.10 & 3.69 \\
\hline 4.67 & 4.17 & 3.87 & 3.50 & 4.05 \\
\hline 4.50 & 4.30 & 4.03 & 3.70 & 4.13 \\
\hline 4.60 & 4.40 & 4.20 & 3.87 & 4.27 \\
\hline 4.47 & 4.30 & 4.10 & 3.80 & 4.17 \\
\hline 4.70 & 4.60 & 4.40 & 4.20 & 4.47 \\
\hline 4.56 & 4.17 & 3.89 & 3.54 & \\
\hline & & SE & $\mathbf{C D}$ & \\
\hline & & 0.03 & 0.07 & \\
\hline & & 0.02 & 0.05 & \\
\hline & & 0.07 & 0.14 & \\
\hline
\end{tabular}




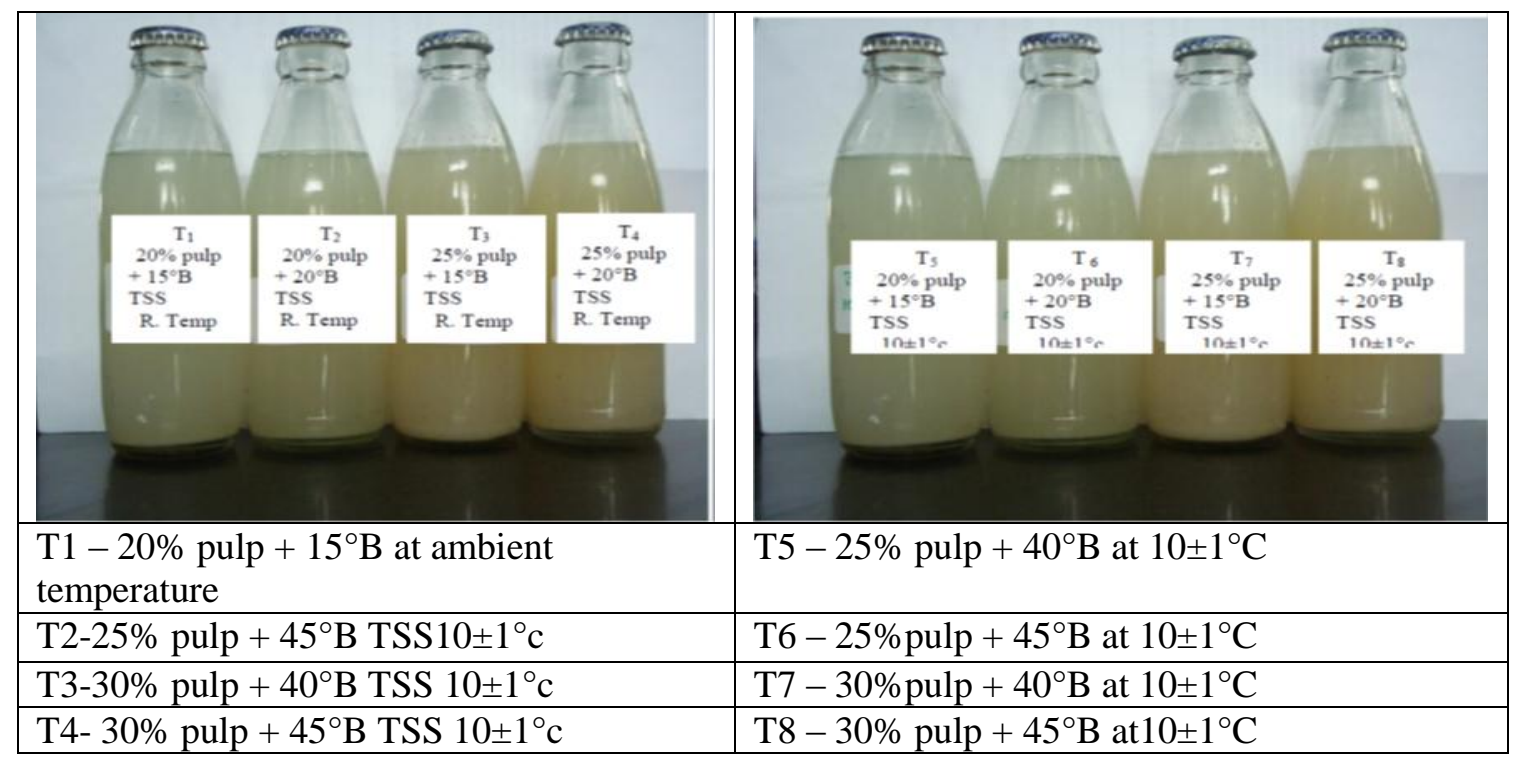

\section{Acidity}

Acidity values recorded in different treatments and days of storage are given in table (1). A significant decrease of acidity from zero days (1.01) to 90 days (0.85) was observed. Among the treatments, T8 recorded higher acidity (0.97) in ber squash over rest of the treatments and it was on par with T7 (0.96) and T5 (0.95). Lesser acidity (0.87) was recorded with $\mathrm{T} 1$.

The interaction effects between storage periods and treatments were found to be significant. Among the interactions T5, T6, T7 and T8 were on par in reducing sugars of ber squash on 30th and 60th day of storage respectively. T8 recorded higher acidity (0.95) after 90 days of storage period.

\section{Ascorbic acid}

The changes in ascorbic acid during storage were presented in table (1). Ascorbic acid content of squash was depended on pulp added to the squash. There was a significant decrease in ascorbic acid content during storage of ber squash at ambient and low temperatures from zero days $(3.57 \mathrm{mg} / 100 \mathrm{~g}$ ) to 90 days (3.33 $\mathrm{mg} / 100 \mathrm{~g})$. Among the treatments highest ascorbic acid content was found in T8 (3.70 $\mathrm{mg} / 100 \mathrm{~g}$ ) during 90 days of storage, and the T1 had the lowest ascorbic acid content (3.28 $\mathrm{mg} / 100 \mathrm{~g})$. Significant interaction effects were observed between treatments and days of storage. There was no significant decrease in ascorbic acid content of ber squash from 60th day of storage in respecting T5, T6 and T7.

\section{Total sugars}

Total sugars values recorded in different treatments and days of storage are given in table (1.4). There was a significant increase in total sugars during storage of ber squash at ambient $\&$ low temperatures from zero days (40.17) to 90 days (40.31). Among the treatments T4 recorded significantly higher total sugars (43.38) in ber squash over all other treatments. It followed by $\mathrm{T} 8$ (43.31). T1 recorded the least total sugars (37.12). The interaction between the days of storage and treatments did not show any significant effect.

\section{Reducing sugars}

Reducing sugars values recorded in different treatments and days of storage are given in table (1). There was considerable increase in reducing sugars content of squash during storage. A significant increase of reducing sugars from zero days (5.78) to 90 days (26.61) was observed. Among the treatments reducing sugars were found to be significantly higher in T2 (20.54) and lowest reducing sugars were 
recorded in T5 (14.01) during storage. The interaction effects between storage periods and treatments were found to be significant. On initial day reducing sugars content in T1 (5.68), T2 (5.90), T3 (5.75), T4 (5.86), T5 (5.62) T6 (5.94) $\mathrm{T} 7$ (5.71) and T8 (5.82) did not differ among themselves. However T6 recorded significantly higher reducing sugars (5.94). On 30th day, T7 (11.99) and T8 (12.34) were on par in recording reducing sugars content in squash (Prasad and Mali, 2006).

\section{Non-reducing sugars}

Non-reducing sugars values recorded in different treatments and days of storage are given in table (1). The non-reducing sugars of ber squash significantly reduced during entire period of storage. Among the treatments T8 recorded significantly higher non-reducing sugars (28.69) in ber squash over all other treatments. It followed by T6 (27.27). T1 recorded the least non-reducing sugars (17.81). Interaction effects showed significant differences between the treatments after 90 days of storage. On 90th day, T1 (7.49) and T3 (7.82) were on par in recording non-reducing sugars content in ber quash.

\section{Overall acceptability}

Overall acceptability scores recorded in different treatments and days of storage are given in table (1). The data shows that the interaction effect was significant. Squash containing maximum pulp (30\%) and total soluble solids $\left(45^{\circ} \mathrm{B}\right)$ had scored maximum points i.e. (4.47) stored at low temperature, and maximum content of pulp (30\%) with minimum total soluble solids $\left(40^{\circ} \mathrm{B}\right)$ scored least points i.e. (3.69) which was stored at ambient temperature. Squash prepared using $30 \%$ pulp with $45^{\circ}$ Brix $\mathrm{TSS}$ and stored at $10 \pm 1^{\circ} \mathrm{c}$ was rated excellent for organoleptic qualities. There was a slight increase in total sugars, total soluble solids, considerable increase in reducing sugars, corresponding decline in non-reducing sugars and meager change in acidity and ascorbic acid content during storage for 90 days. The product was acceptable in condition without colour change and spoilage.

From the research findings of ber products it is concluded that the recipe consisting of $30 \%$ pulp $+45^{\circ}$ Brix at $10 \pm 1{ }^{\circ} \mathrm{C}$ was found to be best for ber squash. However, for preparing the best quality RTS, the recommended recipe is $15 \%$ pulp $+15^{\circ}$ Brix at $10 \pm 1^{\circ} \mathrm{C}$. A recipe of $25 \%$ pulp $+20^{\circ}$ Brix was found to be best to prepare ber nectar of excellent quality. These recipes are highly palatable and acceptable as indicated by the organoleptic evaluation.

\section{References}

Bal J S Chauhan G S (1981) Fixation of maturity standards of ber cv. Umran. Punjab Journal of Horticulture. J. 21(1): 70-75.

Prasad R N and Mali P C 2000 Changes in physico chemical characteristics of pomegranate squash during storage. Indian Journal of Horticulture 57(1):18-20.

Ranganna S 1986 Hand book of Analysis and quality control for fruits and vegetable products. Tata Mc Graw Hill Publishing Company Limited, New Delhi.

Shobha D and Pushpa Bharati (2006) value addition to ber (Zizyphus mauritiana Lamk.) Through preparation of pickle Karnataka Journal of Agricultural Science 20(2): 353-355.

\section{How to cite this article:}

Kavitha, S. and Veeranna Goud, P. 2018. Standardization of the Recipes for Preparation of Ber Squash. Int.J.Curr.Microbiol.App.Sci. 7(04): 3718-3725. doi: https://doi.org/10.20546/ijcmas.2018.704.418 